\title{
„VARÁZSKUCKÓ”: TEHETSÉGGONDOZÁS A MEZÖKÖVESDI ÓVODA ÉS BÖLCSŐDE INTÉZMÉNYEIBEN
}

\section{Szerző:}

\section{Lázár Endréné}

Mezőkövesdi Óvoda és Bölcsőde

A szerző e-mail címe:

gematild@gmail.com

\section{Lektorok:}

\author{
Estefánné Varga Magdolna (Ph.D.) \\ Eszterházy Károly Egyetem
}

Borbélyné Bacsó Viktória (Ph.D.)

Medgyessy Ferenc Gimnázium

és további két anonim lektor...

\begin{abstract}
Absztrakt
A tanulmányban a Mezőkövesdi Óvoda és Bölcsőde intézményeiben megvalósuló tehetséggondozás bemutatása jelenik meg. A tehetséggondozás elsődleges célja az alkotó öröm megalapozása, a kreativitás fejlesztése, az egyéni elképzelések és a fantázia kibontakoztatása. A tanulmányban ismertetjük az intézményben évek óta múködő „Varázskuckó” elnevezésű kreatív program elemeit.
\end{abstract}

Kulcsszavak: óvodapedagógia, tehetséggondozás

Diszciplína: neveléstudomány

\begin{abstract}
TALENT DEVELOPMENT IN THE INSTITUTIONS OF THE MEZÖKÖVESD KINDERGARTEN AND NURSERY SCHOOL

In this study, we present the talent development in the institutions of the Mezőkövesd Kindergarten and Nursery School. The primary goal of talent development is to establish creative joy, development of creativity, and individual ideas and imagination. In the study, we describe the elements of a creative program called 'Varázskuckó' /'Magic Hut'/ that has been operating in the institution for years.
\end{abstract}

Keywords: kindergarten pedagogy, talent development

Discipline: pedagogy

Lázár Endréné (2021): Tehetséggondozás a Mezőkövesdi Óvoda és Bölcsőde intézményeiben. OxIPO - interdiszciplináris tudományos folyóirat, 2021/1, 111-116. doi: $\underline{10.35405 / O X I P O} .2021 .1 .111$ 
A „Varázskuckó” kreativitást kibontakoztató program a Mezőkövesdi Óvoda és Bölcsődében valósul meg, mely négy tagóvodából, egy bölcsődéből és egy élelmezési központból álló intézményegység.

\section{A program célja és alapelve}

Cél: Alkotó öröm megalapozása, kreativitás fejlesztése, egyéni elképzelések, fantázia kibontakoztatása. A gyermekek alkotó-alakító tevékenység-feltételeinek megteremtése, tartalmának, minőségének fejlesztése és szervezeti formáinak biztosítása.

A kis tehetségcsírák megtalálása és segítő, fejlesztő támogatása. Ébredjen fel a gyermekekben az ábrázolás anyagaival, eszközeivel, technikáival való tevékenység vágya. Élményeik, elképzeléseik megjelenítésével egyéni módon tudják alkalmazni a képi kifejezés változatos eszközeit. Alakuljon esztétikai érzékük, a szépség iránti vonzódásuk.

A kis kuckóban a legfontosabb, hogy a gyerekek örömmel jöjjenek, szívesen ismerkedjenek a különböző anyagokkal, technikákkal, tudják megvalósítani ötleteiket, elképzeléseiket és sikerélményhez jussanak.

\section{Alapelv:}

Kiindulópont a gyermekek folyamatos megismerése, fejlődésének nyomon követése. Megfigyelési szempontok: saját tapasztalatok, kérdések, beszélgetések, feladatok, tevékenykedtetés, a gyerekek játékai, tanulási tevékenysége spontán vagy szervezett helyzetben.

A fejlődési naplóba vezetve a megfigyelési eredményeket, láthatóvá válik, hogy a gyermekek, milyen téren, mennyi idő alatt, hogyan fejlődnek. Mely területeken szorulnak további fejlesztésre, mely területeken kiemelkedő képességűek. Ezeknek az ismereteknek a birtokában minden gyermeket differenciáltan lehet fejleszteni.

A tehetséggondozó program alapelve, hogy minél több időt, próbálkozási lehetőséget biztosítsunk a gyermekeknek az elmélyült alkotó tevékenységre, amihez a szükséges feltételeket, ötleteket és eszközöket a program vezetőjének kell biztosítania.

\section{Tehetségazonosítás és beválogatás}

Az óvodában nem beszélhetünk még azonosított tehetségekről, ennek ellenére lényeges feladatunk, hogy a differenciálás eszközrendszerével, komplex, játékos tevékenységekkel fejlesszük a gyermekek személyiségét.

Két tagóvodánkban múködik kreatív tehetséggondozás: az egyikben „Ügyes kezek, kis művészek" néven fut, mely 2017-ben indult, a másikban 2020-ban kezdődött „Varázskuckó” néven múködő kreatív tehetséggondozás.

„Varázskuckó” nevű kreatív csoportba bárki bekapcsolódhat. Több olyan gyermek is részt vesz a tevékenységekben, 
akiknek finommotorikája, szem-kéz koordinációja kiemelkedő, képesek az összpontosításra, az együttműködésre, megfelelő szociális és motivációs szinttel rendelkeznek. A vizualitás területén átlag feletti speciális képességekkel, egyéni vizuális önkifejezéssel rendelkeznek.

A gyerekek a szülők kérése, illetve az óvodapedagógusok javaslata alapján kerülnek be a tehetséggondozó csoportokba.

\section{Tehetséggondozás a kreatív „Varázskuckóban”}

Fejlesztési területek:

- Értelmi: Vizuális percepció, belső kép fejlesztése, vizuális technikák megismerése, elsajátítása, gyakorlása.

- Szociális: Egymás munkájának elismerése. A közös alkotás örömének átélése. Erkölcsi tulajdonságok erősítése (kitartás, segítőkészség, újra próbálkozás).

- Kommunikáció: A technikák megnevezésével szókincsbővítés. A felhasznált eszközök neveinek megismertetése. Felnőtt-gyermek, gyermek-gyermek közötti kommunikáció erôsítése.

- Testi: Finommotorika fejlesztése. Szem-kéz koordináció alakítása. Nagymozgások, lazítógyakorlatok.

- Szervezés: A csoportszobában a tevékenységhez szükséges aszta- lok, székek elhelyezése, asztalok leterítése, eszközök előkészítése.

Módszerek:

- Motiválás, új technikák, új eszközök megismertetése, kipróbálása. Megismert technikák öszszehasonlítása, gyakorlása, kísérletezések, magyarázat.

- Differenciálás: Képességeikhez mért technikák biztosítása, érdeklődésük szerinti választás lehetőségének biztosítása. A feladatok nagyságának, mennyiségének, segítségnyújtás mértékének differenciálása.

- Értékeléssel pozitív megerősítés, önbizalom erôsítés, társas kapcsolatok, kommunikáció, egymás segítésének erősítése.

Foglalkozások leírása: a tehetséggondozó foglalkozások tervezésénél figyelembe vesszük a gyermekek egyénenként eltérő biológiai és fejlődési ritmusát, igényeit, szükségleteit, kitartását, finommotorikájának fejlettségét az évszaknak megfelelő aktualitásokat. Biztosítjuk az optimális személyiségfejlődéshez, egyéni képességeik kibontakoztatásához nélkülözhetetlen érzelmi biztonságot, derűs, szeretetteljes légkört. Segítjük a gyermeket szociális érzékenységének fejlődésében és éntudatának alakulásában, teret engedve önérvényesítési törekvésének. Minden alkalommal érdekes, nem szokványos anyagokat használunk például szappan- 
buborék, só, tinta, fümag, borotvahab, ananászlevél, hab-verő, cipőtalp, lufi, pattogatott kukorica, ceruzafaragás, linóleum, dombormintás papírtörlő, függöny, csipke, fürészporos tapéta...

A Varázskuckóban ezekkel az anyagokkal csodákat varázsolunk, különleges nyomatokat, festményeket készítünk. Mivel meseszép lesz minden elkészült munka, ez erősíti a gyerekek önbizalmát, fejleszti képzelőerejüket, fantáziájukat, képalkotó készségüket, rész-egészlátásukat, alak és formaállandóságukat, finommotorikájukat, kitartásukat. Megismerik azt is, hogy egy-egy tárgy felhasználása eltérhet eredeti rendeltetésétől: pl. fésű, habverő, cipőtalp, hiszen mesés nyomatokat, karcokat, mintákat lehet ezekkel a tárgyakkal készíteni. A matyó népművészet eszközeit, a népi kultúra átörökítését is bevonva valósítjuk meg a tehetséggondozó kuckókat.

Demonstrációképpen az 1. táblázat foglalja össze a 2019/2020-as év tehetséggondozási munkatervét és néhány képet, amit a gyerekek készítettek a Varázskuckóban.

A tehetséggondozó múhelyben folyó munka közben a gyerekek nagyon sokat fejlődnek, egyre inkább bíznak magukban és még szívesebben vesznek részt mindenféle (nem csak kreatív) tevékenységben.

A tehetséggondozók működését, tárgyi eszközeinek beszerzését az Önkormányzat, valamint pályázatok, óvodai Alapítványok és a szülők segítségével valósítjuk meg. Alapanyagokat gyűjtőmunkával, újrahasznosítással is beszerzünk.

A különböző tehetséggondozó műhelyeket az óvodák pedagógusai vezetik.

\section{Hatásvizsgálat}

A tehetségfejlesztő programot a nevelési év végén hatásvizsgálatnak vetjük alá. A nevelőtestülettel megbeszéljük mit valósítottunk meg a tehetséggondozó program kitűzött céljaiból, a megvalósítás hozott-e eredményeket? A hatásvizsgálat szempontjait az éves nevelési tervben rögzítjük a kitűzött célokkal összhangban.

A gyermekek fejlődését a Fejlődési naplóban vezetjük, így folyamatosan nyomon tudjuk követni, hogy mely területeken, hogyan fejlődik a gyermek.

Az iskolákkal nagyon jó kapcsolatban vagyunk, így az óvodások iskolába kerülése után, folyamatos visszajelzéseket kapunk róluk.

Azok a gyerekek, akik tehetséggondozó programjainkon vettek részt, iskolába kerülve erősebb feladattudattal, kitartással, nagyobb önbizalommal és kíváncsisággal tudták magukat belevetni a tanulás rejtelmeibe. Könnyebben sajátították el az írást, olvasást. A tanítói visszajelzések a gyerekek fejlődésével kapcsolatban nagyon pozitívak voltak. Legtöbbször a kreativitást, logikus gondolkodást, lényeglátást, összefüggések meglátását, a képzelet, fantázia, finommotorika fejlettségét, találékonyságot, kitartást, kiemelkedő eszközhasználatot emelték ki. 
1. táblázat: Tehetséggondozó Varázskuckó éves terve 2019/2020 (forrás: a Szerzô).

\begin{tabular}{|c|c|c|c|}
\hline Hó & Technika & Téma & Eszköz \\
\hline $\begin{array}{l}\text { Szept. } \\
2 \text { alk. }\end{array}$ & $\begin{array}{l}\text { Olajpasztell krétára festés tintával: } \\
\text { Fehér lapra fehér olajpasztellel csíkok } \\
\text { húzása, majd lefestése, színes } \\
\text { tintával, háttérnek }\end{array}$ & Háttérkészítés & $\begin{array}{l}\text { fehér rajzlap, fehér } \\
\text { olajpasztell, kréta, színes } \\
\text { tinta, pasztell halvány } \\
\text { színben }\end{array}$ \\
\hline $\begin{array}{l}\text { Okt. } \\
2 \text { alk. }\end{array}$ & $\begin{array}{l}\text { A tintával, olajpasztellel elkészült } \\
\text { alapra tulipánok festése élénk színű } \\
\text { tintával }\end{array}$ & $\begin{array}{ll}\text { Tulipánok } & a \\
\text { kerítés előtt } & \end{array}$ & $\begin{array}{l}\text { Az előző foglalkozáson } \\
\text { elkészült háttér tulipán } \\
\text { sablonok negatív mintája } \\
\text { élénk színú tinta, ecset }\end{array}$ \\
\hline $\begin{array}{l}\text { Nov. } \\
3 \text { alk. }\end{array}$ & $\begin{array}{l}\text { Festék széthengerezése, majd } \\
\text { visszakaparással mintázat kialakítása }\end{array}$ & $\begin{array}{l}\text { Zöld háttér } \\
\text { készitése }\end{array}$ & $\begin{array}{l}\text { Zöld és sárga festék, } \\
\text { szivacshenger, különböző } \\
\text { fogazatú műanyag lapok }\end{array}$ \\
\hline $\begin{array}{l}\text { Dec. } \\
2 \text { alk. }\end{array}$ & $\begin{array}{l}\text { Szivacshengerezés, } \\
\text { szivacsnyomdázás, háttértechnika, } \\
\text { Ragasztás, kivágás, összeillesztés }\end{array}$ & $\begin{array}{l}\text { Tűzolt } \\
\text { vezete }\end{array}$ & $\begin{array}{l}\text { Tűzoltóautó elemei kivág- } \\
\text { va, ragasztó, szivacshen- } \\
\text { ger, szivacsdarabok, fes- } \\
\text { ték, fénykép a gyermekről, } \\
\text { ô vezeti a tűzoltó autót }\end{array}$ \\
\hline $\begin{array}{l}\text { Jan. } \\
4 \text { alk. }\end{array}$ & $\begin{array}{l}\text { Linónyomat: Linómetszetre festék } \\
\text { felhordása hengerrel, majd rajzlap } \\
\text { ráhelyezése és áthengerezése, } \\
\text { lenyomatozása }\end{array}$ & $\begin{array}{l}\text { "Focista } \\
\text { leszek" }\end{array}$ & $\begin{array}{l}\text { Linómetszet, henger } \\
\text { festék, műszaki rajzlap }\end{array}$ \\
\hline $\begin{array}{l}\text { Febr. } \\
3 \text { alk. }\end{array}$ & $\begin{array}{l}\text { Színes homok, és színes gríz } \\
\text { ragasztása. Hungarocell tojások } \\
\text { díszítése. Ragasztással „minta” } \\
\text { rajzolása a tojásra, majd beleforgatása } \\
\text { a színes homokba, színes grízbe }\end{array}$ & Tojás díszítése & $\begin{array}{l}\text { Kis tálkákban: színes } \\
\text { homok, színes gríz, } \\
\text { hungarocell tojás,ragasztó } \\
\text { szalag }\end{array}$ \\
\hline $\begin{array}{l}\text { Márc. } \\
2 \text { alk. }\end{array}$ & $\begin{array}{l}\text { Lufival festés, háttér készítése. A } \\
\text { puhára fújt lufikat festékbe mártva } \\
\text { színes háttereket készítünk. } \\
\text { Narancsos árnyalatban, zöldes } \\
\text { árnyalatokban és lilás árnyalatban }\end{array}$ & Háttér] & $\begin{array}{l}\text { Kb. ököl nagyságúra } \\
\text { felfújt léggömbök, } \\
\text { festékek, fehér műszaki } \\
\text { rajzlap }\end{array}$ \\
\hline $\begin{array}{l}\text { Márc. } \\
2 \text { alk. }\end{array}$ & $\begin{array}{l}\text { Lufival festés. A puhára fújt kb. } \\
\text { ökölnyi lufik alját festékbe nyomva } \\
\text { szirmokat alakítunk ki árvácskához, } \\
\text { pipacsokhoz. Szirmok kivágása után } \\
\text { 3D-s ragasztóval virág kialakítása. } \\
\text { Levél kivágása, felragasztása. }\end{array}$ & $\begin{array}{l}\text { Pipacsok, } \\
\text { árvácskák } \\
\text { sol }\end{array}$ & $\begin{array}{l}\text { Kb. ököl nagyságúra } \\
\text { felfújt réggömbök } \\
\text { festékek, fehér műszaki } \\
\text { rajzlap. 3D ragasztó, az } \\
\text { elkészült háttér alapok, } \\
\text { ollók }\end{array}$ \\
\hline
\end{tabular}




\begin{tabular}{|c|c|c|c|}
\hline $\begin{array}{l}\text { Ápr. } \\
2 \text { alk. }\end{array}$ & $\begin{array}{l}\text { Színes festékcsíkok kinyomása a lap } \\
\text { első negyedére, majd lapos ecsettel } \\
\text { tovább húzás, a lap befedése a } \\
\text { festékkel. Színes árnyalatok készítése } \\
\text { zöld, sárga hangulattal, minta } \\
\text { karcolása }\end{array}$ & $\begin{array}{l}\text { Háttér } \\
\text { készítése }\end{array}$ & $\begin{array}{l}\text { Zöld, sárga árnyalatai, } \\
\text { festék, lapos ecset, fehér } \\
\text { múszaki rajzlap, műanyag } \\
\text { változó fogazatú lapok a } \\
\text { karcoláshoz }\end{array}$ \\
\hline $\begin{array}{l}\text { Ápr. } \\
2 \text { alk. }\end{array}$ & $\begin{array}{l}\text { Színes granulátumot, színes grízt a } \\
\text { beragasztózott felületre szórunk, így } \\
\text { kialakítva a mintát, majd hajlakkal } \\
\text { rögzítjük }\end{array}$ & $\begin{array}{l}\text { Csigaház } \\
\text { díszítése }\end{array}$ & $\begin{array}{l}\text { Csiga sablon, kis } \\
\text { tálkákban színes homok, } \\
\text { színes gríz, ecset, ragasztó, } \\
\text { hajlakk, fehér múszaki } \\
\text { rajzlap }\end{array}$ \\
\hline $\begin{array}{l}\text { Máj. } \\
2 \text { alk. }\end{array}$ & $\begin{array}{l}\text { Változó mintájú bordás felületek } \\
\text { átsatírozása olaj pasztellkrétával pl.: } \\
\text { csipkeanyagok, cipó és papucstalpak, } \\
\text { falevelek, páfránylevél, dombor- } \\
\text { nyomott felületek, bársony, szövött } \\
\text { anyagok, necc harisnya }\end{array}$ & $\begin{array}{l}\text { Háttér } \\
\text { alapkészítés }\end{array}$ & $\begin{array}{l}\text { olajpasztellkréták, erős, } \\
\text { élénk színekben, külön- } \\
\text { böző domború felületű } \\
\text { anyagok: pl.: csipke, } \\
\text { szövet, bársony, falevelek, } \\
\text { páfránylevél, necc haris- } \\
\text { nya, cipó és papucstalp, } \\
\text { zöldséges, gyümölcsös } \\
\text { hálók }\end{array}$ \\
\hline $\begin{array}{l}\text { Máj. } \\
2 \text { alk. }\end{array}$ & $\begin{array}{l}\text { Az elkészült alapból és háttérből } \\
\text { kisebb, nagyobb halak kivágása, vízi } \\
\text { növények, kagylók, csigák, kövek } \\
\text { kivágása }\end{array}$ & $\begin{array}{l}\text { Akváriumban } \\
\text { úszkáló halak } \\
\text { i) } 1 \text { (y }\end{array}$ & $\begin{array}{l}\text { Alap, háttér lapok, olló, } \\
\text { kisebb-nagyobb ral } \\
\text { sablonok, ragasztó, 3D-s } \\
\text { ragasztó }\end{array}$ \\
\hline
\end{tabular}

